\title{
OCCURRENCE OF PIGEON DISEASES AT KHULNA SADAR, BANGLADESH
}

\author{
T. K. Paul ${ }^{1 *}$, M. R. Amin ${ }^{1}$, M. A. Alam ${ }^{3}$, M. K. Rahman' ${ }^{1}$ Y. A. Sarker ${ }^{2}$ and M. K. Rizon ${ }^{4}$ \\ ${ }^{1}$ Department of Pharmacology and Physiology, Patuakhali Science \& Technology University, Dumki, Patuakhali-8602, \\ Bangladesh; ${ }^{2}$ Department of Pharmacology, ${ }^{3}$ Department of Microbiology, ${ }^{4}$ Department of Agricultural Statistics, \\ Bangladesh Agricultural University, Mymensingh-2202, Bangladesh
}

\begin{abstract}
A study on pigeon diseases at Khulna sadar and surrounding private farms was done to determine the occurrence of the common pigeon diseases. A total of 502 diseased pigeon were examined. According to age, they were classified into three categories squab (1-2 weeks), young (30-90 days) and adult (>90days). Those diseases were identified clinically by postmortem examination and laboratory testing, were carried out in veterinary hospital at Khulna from March 2013 to February 2014. Out of 502, 20.32\% were salmonellosis, $18.92 \%$ were pigeon pox, $11.95 \%$ were canker. Pigeon pox found high level in June-July. Among other diseases parasitic infestation (31.67\%) was more prevalent. Disease varies significantly $(\mathrm{P}<0.01)$ with season, where summer $(57.37 \%)$ is more prevalent. Rate of diseases (salmonellosis and pigeon pox) affection significantly $(\mathrm{P}<0.01)$ varies with age. Young are more susceptible with salmonellosis and pigeon pox. This study was done first time at Khulna and right time to take necessary steps saving pigeon farming.
\end{abstract}

Keywords: Pigeon, disease, prevalence, pigeon hernia

\section{INTRODUCTION}

Poultry industry is the most effective and economical source of animal protein in shortest possible time, but still it is unable to narrow down the animal protein supply and demand gap because of increasing future demands. Although commercial broiler and layer farm fill up present requirement of protein, but people feel monotonous with chicken meat and they desire another safe meat. So many people begin pigeon farming to fulfill public demand and become economically enriched. According to Agricultural Sample Survey in 2013, Bangladesh had a population of 10.8 million pigeons of which $11 \%$ were kept on what is termed commercial farms. Such farms were however not identified. In no division did pigeons kept in commercial farm conditions exceed $1 \%$ of the poultry population (Dolberg, 2008). In Bangladesh, domestic pigeon has been reared for meat purposes for many years. The domestic pigeon was derived from the rock dove or rock pigeon or common pigeon of which scientific name is Colomba livia. Pigeons fall into three groups i.e. poultry pigeons, carrier and racing pigeons. Their distribution has made them readily accessible subjects for study. They have accustomed to live in close association with human beings and they are readily bred to provide squabs for the table. Besides some foreign pigeon like Porter, King etc. cannot hatch their egg but our indigenous pigeons are able to hatching of those pigeon egg. So it is the good scope for us. In Bangladesh, the pigeon is one of the indigenous species of poultry, reared conventionally by the poor farmers for maintaining their livelihood. In past female household members are engaged with pigeon rearing. But now a day's most people are engaged with pigeon rearing as second occupation even student. Pigeon are rather prolific and there is a lot of demand of squab meat in the market due to its delicacy and taste (Asaduzzaman et al., 2012). Poultry producers are looking forward for some substitute of chicken meat which in the future may come in the form of pigeon and quail meat to contribute towards the increase in gross domestic production (GDP) under the livestock sector (Basit et al., 2006). Pigeon rearing is going through a process of small-scale similar to chicken rearing in the coastal belt of Bangladesh. Pigeon rearing should be explored more as it one of the promising species for future income earning opportunities for many people, offering scope for reducing the unemployment problem in Bangladesh. In recent years at Khulna, like indigenous chicken and ducks, our domestic pigeons have emerged as a small-scale commercial entrepreneurship and have proved to be a sustainable livelihood proposition for rural farmers under traditional system of management. The growth and popularity of squabs are high and increasing. This is good business for the pigeon farmer, but recently pigeon are affected with different types of disease recorded by district veterinary hospital, Khulna. For this interest the study was done to investigate which diseases were commonly affect pigeon and the cause of pigeon death and decrease production.

*Corresponding e-mail address: tarundvm14@gmail.com 


\section{T. K. Paul and others}

\section{MATERIALS AND METHODS}

The study was conducted at District Veterinary Hospital, Khulna from March 2013 to February 2014. The pigeons were carried out by the farmers of Khulna metropolitan and surrounding area to the District Veterinary Hospital for diagnosis of different diseases and their treatment. A total of 502 pigeons were diagnosed based on clinical signs, post-mortem findings and laboratory test. A questionnaire was developed for data collection from the farmers. The farmers of pigeon farms were individually interviewed. Physical examination was done for each attending. Based on questionnaire data on breed, age, sex, feeding, housing system was recorded. Data on diagnostic and therapeutic protocol used were also collected.

Clinical signs were recorded including inappetance, depression, weakness, loss of body weight, greenish diarrhea, watery diarrhea, ruffled feather, cheesy material in mouth, one eye swelling, and occulo-nasal discharge. These signs were detected by using general physical examination of mouth, nostril, eye, feather, breast mussel and feces.

Laboratory test was performed to identify malaria. Malaria test was performed using Giemsa's solution which is a mixture of methylene blue, eosin, and Azure B. The stain is usually prepared from commercially available Giemsa powder. A thin film of the specimen (usually swab collected from pharynx, cloacae and blood collected from wing vein and feces)on a microscope slide is fixed in pure methanol for 30 seconds, by immersing it or by putting a few drops of methanol on the slide. The slide is immersed in a freshly prepared 5\% Giemsa's stain solution for 20-30 minutes (in emergencies 5-10 minutes in 10\% solution can be used), then flushed with tap water and left to dry. Characteristic clinical signs used to detect diseases were as follows:

\section{Canker}

Infected birds show a definite reduction in activity, ruffled feathers, loss of weight, increased water intake, and diarrhea. Nodules can usually be seen or if in the crop wall can usually be felt as firm mobile lumps ranging in size from $0.5 \mathrm{~cm}$ to $4 \mathrm{~cm}$ in diameter. Cheesy yellowish deposits can often be observed in the mouth or throat (Harry, 2007).

\section{Coccidiosis}

Infected birds have little or no desire to eat or drink, will remain puffed up on perches, lack any desire to move and often close their eyes. Droppings are usually very loose, greenish in color and may become very watery. Loss of weight occurs, and death can occur in young birds (Walker, 2014).

\section{Colibacillosis}

Since the Escherichia coli bacteria can manifest themselves in any part of the pigeon's body, symptoms can be diverse. Most often young will die in the nest, adult birds will become listless and lose weight, and their droppings will become loose, mucous, and greenish yellow in appearance. Young birds dying of acute septicemia have few lesions except for an enlarged, hyperemic liver and spleen with increased fluid in body cavities (Nolan, 2013).

\section{One-Eye colds}

A watery or mucous discharge in only one eye is usually the symptom most commonly noticed, but occasionally both eyes will have watery appearances. Sometimes one eye can become completely shut, depending upon the degree of infection.

\section{Salmonellosis}

Salmonella flagellates can be found throughout the body in severely infected birds. Thus, a variety of symptoms is possible. Most adult birds will show rapid weight loss, along with somewhat loose, greenish droppings. Some birds may develop swelling in the leg joints or feet, or may develop wing boils. Other birds may have the "twisted neck" syndrome commonly associated with PMV. Baby birds will often show labored breathing or die in the nest before the second week after hatching. Sometime young die in the egg.

\section{Pigeon pox}

Small whitish wart-like lesions appear on the head, feet legs and beak areas. These deposits can grow to become large yellowish bumps which, if removed, may ooze blood. In time, these lesions will dry and fall off, so it is our advice to leave them alone. 


\section{Coryza}

The classic symptoms of respiratory infections include mucous in the throat, open beak and heavy breathing, gasping or gurgling while breathing, watery discharge from eyes, sometimes associated with swelling in the eye area. Other symptoms include discharge from the nasal area.

\section{Sour crop}

This very common disease is caused by a fungus infection of the digestive tract. It is often associated with excessive use of antibiotics. Infected birds become listless, won't eat, lose weight, develop a water-filled crop and vomit often. This vomit often has a very putrid odor. Sometimes, in laser cases, thrush will show itself as just small whitish spots in the throat, which causes confusion with canker, another much less noticed symptoms, usually found only in adult birds, is feather pulling.

\section{Worm infection}

The most common worms found in pigeons today are roundworms hair worms, stomach wall worms, gapeworms, stronglylids and tapeworms. The symptoms vary with the type of infestation, and conceivably pigeons can live with slight infestations and show no ill effects. Severe infestations generally cause droopiness, loss of weight and some diarrhea. Gapeworms can cause breathing problems. The best way to determine if a worm problem exists is to have the droppings checked.

\section{External parasite}

The most common external parasites that pester our birds are feather lice, red mites, pigeon flies, and mosquitoes. Pigeon flies bite the birds often, and besides causing considerable discomfort, they can be a major cause of pigeon malaria. Mosquitoes would have to be considered the next worst parasite, simply because they are found in almost all climates. They are the most common carrier pigeon pox virus.

\section{Pigeon diarrhea}

Sometimes our birds develop diarrhea, often just after medication treatments or high stress, so we wonder how they could be sick when we have just treated them.

\section{Newcastle disease}

This disease is occurring with Newcastle disease virus. It spread rapidly with other bird through contaminated feces, saliva, and discharge from nostril. Greenish diarrhea, watery feces are found in case of intestinal form of disease. Respiratory sign like dyspnea, coughing is found in case of respiratory form of disease. Nervous in coordination is found in case of nervous form disease.

\section{Nutritional deficiency}

This is the common problem in pigeon rearing. In this case vitamin B1, B2 deficiency is most commonly seen. Affected birds suffer from nervous dysfunction (neck paralysis), birds cannot eat feed and water; as a result they cannot survive and die within few days (Samad, 2013).

\section{Statistical analysis}

Collected data were analyzed by SPSS 20 version software \& MS excel 2010.

\section{RESULTS AND DISCUSSION}

During one year of study period a total of 14 diseases were found from 502 (squab 100, young 133, adult 269) diseased pigeon. Out of 502, 20.32\% were salmonellosis, $18.92 \%$ were pigeon pox, $11.95 \%$ were canker and rests of the disease were below $10 \%$ (Table 1).

Among the infectious diseases, parasitic diseases were mostly found (31.67\%) followed by bacterial $(29.28 \%)$, viral $(25.5 \%)$, fungal $(5.18 \%)$ and others $(8.37 \%)$ (Table 2$)$. Within others mixed infection, one-eye-cold, deficiency and hernia were found. Among the collected data from my study period, parasitic case was higher than others. As causes of parasitic infestation found within those farm and pigeon loft, the owner does not use regular doses of anthelmintic and irregular cleaning of pigeon nest. Other infection occurs for their unhygienic management. These area farmers haven't enough knowledge about pigeon rearing and management. 


\section{T. K. Paul and others}

Table 1. Occurrence of different diseases of pigeon

\begin{tabular}{lll}
\hline Disease & Number & Percentages $(\%)$ \\
\hline Canker & 60 & 11.95 \\
Coccidiosis & 18 & 3.59 \\
Colibacillosis & 25 & 4.98 \\
One-Eye cold & 15 & 2.99 \\
Salmonellosis & 102 & 20.32 \\
Pigeon pox & 95 & 18.92 \\
Pigeon Malaria & 16 & 3.19 \\
Coryza & 20 & 3.98 \\
Worm Infection & 30 & 5.98 \\
External Parasite & 35 & 6.97 \\
Pigeon diarrhea & 25 & 4.98 \\
Newcastle Disease & 33 & 6.57 \\
Hernia & 2 & 0.4 \\
Sour Crop & 26 & 5.18 \\
\hline
\end{tabular}

Table 2. Occurrence of different diseases of pigeon based on their causal agents

\begin{tabular}{lllll}
\hline Types of disease & No. Affected & Prevalence $(\%)$ & Chi-Square value & P value \\
\hline Bacterial & 122 & 24.30 & & \\
Viral & 128 & 25.50 & $152.522^{\mathrm{a}}$ & $.000^{* *}$ \\
Fungal & 26 & 5.18 & & \\
Parasitic & 159 & 31.67 & & \\
Deficiency & 25 & 4.98 & & \\
Others & 42 & 8.37 & & \\
\hline
\end{tabular}

According to Ali et al. (2011) seasons were classified into 3. Summer consists of March to May, rainy consists of June to October and winter consists of November to February. In summer, pigeons are more severely affected with different diseases like bacterial, viral and deficiency diseases are found (Table 3). But in rainy season fungal infection is found more than other season, because farmer supply feeds to their pigeon, which sometime dumpy and fungus contaminated.

Table 3. Occurrence of different diseases of pigeon varies with season

\begin{tabular}{lllll}
\hline Season & No. Affected & Prevalence $(\%)$ & Chi-Square value & P value \\
\hline Summer & 288 & 57.37 & & \\
Rainy & 145 & 28.88 & $147.781^{\mathrm{a}}$ & $.000^{* *}$ \\
Winter & 69 & 13.74 & & \\
\hline
\end{tabular}

According to age, 502 pigeons were classified into three categories squab (1-2 weeks), young (30-90 days) and adult (>90days). Salmonella affected squab die within one week and sometime young found die within egg (Table 4). Salmonella infection occurs in pigeon farms through infected pigeon which were taken from the market by the farmer and give access to nest with other pigeon without any treatment or quarantine. Another way feeds are contaminated with salmonella by rodents, it's a common mater in this area.

Table 4. Salmonella affection and mortality rate in different stage of pigeon life

\begin{tabular}{llllll}
\hline Stage of life & No. Affected & No. Death & Percentages (\%) & $\begin{array}{l}\text { Chi-Square } \\
\text { value }\end{array}$ & P value \\
\hline Squab (Age under 1-2week) & 55 & 55 & 100 & & \\
Young (30days-90days) & 25 & 20 & 80 & $72.603^{\text {a }}$ & $.000^{* *}$ \\
Adult $>$ 90 days & 22 & 2 & 9 & & \\
\hline
\end{tabular}


Pigeon are severely affected with pigeon pox both squab and adult. Pigeon pox affection varies significantly $(\mathrm{P}<0.01)$ with age (Table 5). In case of adult cure with treatment and management, but squab die. Because they don't eat feed and water due to lesion and pain in head region.

Table 5. Prevalence of pigeon pox

\begin{tabular}{llllll}
\hline Pigeon & No. Affected & No. Death & Percentages $(\%)$ & Chi-Square value & P value \\
\hline Squab & 45 & 45 & 100 & $53.333^{\text {a }}$ & $.000 * *$ \\
Adult & 50 & 10 & 20 & & \\
\hline
\end{tabular}

Pigeon hernia found two out of 502. Surgical correction of hernia was done, but it recurred again after two weeks. Then second time correction sustain.

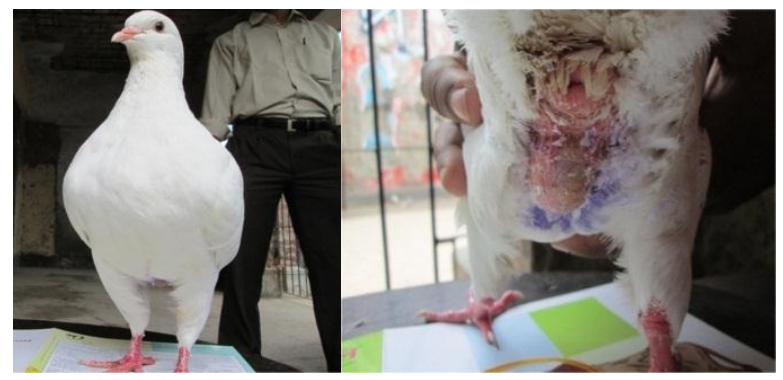

Fig.1.Hernia in pigeon

Fig. 2. Ventral aspect of pigeon hernia

Pigeon farming is the most productive business in recent time. Many people both village and town is engage with pigeon rearing for quick return of their investment. It is more popular business for the farmer and creates scope by elite class people keeping pigeon for their entertainment. But they have no enough knowledge about pigeon rearing and management; resulting pigeon are affected with various diseases. Farmers sometime lose their investment money. So pigeon farmers would be benefited utilizing the information regarding diseases from the current research.

\section{ACKNOWLEDGEMENTS}

The authors are grateful to K. Mustafa, Veterinary Surgeon, Khulna District Livestock Hospital for technical support.

\section{REFERENCES}

1. Ali MH, Bhuiyan MKJ and Alam MM (2011). Retrospective epidemiologic study of diseases in ruminants in Khagrachari Hill Tract District of Bangladesh. Bangladesh Journal of Veterinary Medicine 9: 145-153.

2. Asaduzzaman M, Mahiuddin M, Howlider MAR, Hossain MM and Yeasmin T (2012). Pigeon farming in Gouripur Upazilla of Mymensingh District. Bangladesh Journal of Animal Science 38: 142-150.

3. Basit MT, Pervez K, Avais M and Rabbani I (2006). Prevalence and chemotherapy of nematodes infestation in wild and domestic pigeons and its effects on various blood components. Journal of Animal and Plant Science 16: 24-27.

4. Dolberg $\mathrm{F}(2008)$. FAO animal production and health division, Poultry sector country review, Bangladesh.

5. Harry G (2007). "Trichomonas gallinae." Worcestershire Biological Records Centre.

6. Samad MA (2013). Avian Medicine. $2^{\text {nd }}$ edn., Mymensingh: LEP Publications.

7. Nolan LK (2013). Overview of Colibacillosis in Poultry: Colibacillosis. Merck Veterinary Manual. Available at: http://www.merckvetmanual.com/mvm/poultry/colibacillosis/overview_of_colibacillosis_in_poultry.html [Accessed December 18, 2014].

8. Walker DC (2014). Australian Pigeon Company. Available at: http://www.auspigeonco.com.au/Articles/Race_Form_Part2.html [Accessed December 7, 2014]. 